\title{
Белковая композитная смесь на основе морских объектов: товароведные и биокоррегирующие свойства
}

\author{
Александра Данилова, Лидия Шульгина, Юрий Приходько*, \\ Юрий Шульгин
}

Дальневосточный федеральный университет, г. Владивосток, Россия Тихоокеанский филиал ВНИРО («ТИНРО»), г. Владивосток, Россия

Информация о статье

Поступила в редакичию:

23.05.2019

Принята к опубликованию: 06.10.2019

УДК 615.27

JEL L66

\section{Ключевые слова:}

ферментативные гидролизаты, композитные смеси, технология, рецептура, моноалкилглицерины, липидный обмен

\section{Keywords:}

enzymatic hydrolysates, composite mixtures, technology, formulation, monoalkylglycerols, lipid metabolism

\begin{abstract}
Аннотация
Разработана технология получения новых белковых композитных сухих смесей для введения в рациион питания людей с метаболическими нарушениями или входящих в группу риска. В качестве основы для получения белковых композитных смесей предложены ферментативные гидролизатыл из пищевых тканей дальневосточных двустворчатых (гребешка приморского и спизуль сахалинской) и головоногих моллюсков (кальмара командорского и осьминога Дофлейна). Включение белковых композитных смесей, обогащуенных природными моноалкилглицеринами, в рацион питания людей с нарушением липидного обмена оказывало положительный эффект на липидный спектр в виде снижения уровня общего холестерина, триглицеридов и липопротеидов низкой плотности, а также индекса атероген-
\end{abstract} ности.

Protein Composition based on Marine Object:

Trading and Bio-Corrective Properties

Alexander Danilov, Lidia Shulgin, Yuri Prikhodko, Yuri Shulgin

\section{Abstract}

A technology has been developed for obtaining new protein composite dry mixtures for introduction into the diet of people with metabolic disorders or at-risk group. As a basis for the production of protein composition, enzymatic hydrolysates from food bivalves of the Far Eastern (Patinopecten yessoensis, Spisula sachalinensis) and cephalopod mollusks (Berryteuthis magister, Octopus dofleini) are proposed. Viscous creamy hydrolysate was obtained for $2.2 \pm 0.3 \mathrm{~h}$ with the following parameters: the hydromodule $-1: 1$; the activity of the enzyme Protamex $-0.7 \pm 0.3 ; p H 6.0 \pm 0.5$; temperature $-37 \pm 0.3^{\circ} \mathrm{C}$. The

* Автор для связи: prikhodko.yиv@dvfu.ru DOI: https://dx.doi.org/10.24866/2311-2271/2019-3/141-151 
hydrolysis depth was $29.2 \pm 34.6 \%$, the viscosity of the hydrolysates was $11.3-11.8 \mathrm{~m}^{2} / \mathrm{s}$. Drying of the hydrolysates was performed by the method of freeze-drying. Dry hydrolysates from mollusks were used in the recipes of composite mixtures; their mass fraction was 67.8-69.8\%. To increase the nutritional value and improve the organoleptic characteristics, food and aromatic components were introduced into the composition of composite mixtures, and to improve dietary properties - a natural 1-O-alkylglycerol esters. In the final composition mixtures, the content of digestible proteins was 48.9-51.0\%, fat $-7.9-8.7 \%$, carbohydrates $-19.2-21.8 \%$, mineral substances $-7.9-9.0 \%$. Dry protein composite mixtures were packaged in bags of polymer film materials of 20-30 g each, in which the content of monoalkylglycerols was 360.0-720.0 mg, which allows to satisfy the daily need of the human body for them by $36.0-72.0 \%$. The inclusion of protein composite mixtures enriched with natural monoalkylglycerols in the diet of people with lipid metabolic disturbances had a positive effect on the lipid spectrum in the form of lowering total cholesterol, triglycerides and low-density lipoproteins, as well as atherogenic index.

\section{Введение}

В современной диетологической практике с целью улучшения пищевых рационов для отдельных категорий населения в последние десятилетия рекомендованы сухие питательные смеси, обладающие высокой биологической ценностью и выраженными лечебно-профилактическими свойствами $[1,2]$. Они предназначены для диетического (лечебного и профилактического) питания взрослых и детей старше трех лет в качестве компонента для приготовления готовых блюд. Белковые композитные смеси рекомендуются вводить в состав стандартных, специальных и индивидуальных диет с целью оптимизации пищевых рационов, коррекции пищевой ценности и сбалансированности состава диетических блюд.

Перспективной основой белковых композитных смесей для профилактики и коррекции метаболических нарушений в организме человека являются ферментативные гидролизаты из животного или растительного сырья, в которых основная часть белков представлена биодоступными пептидами $[3,4]$. Известно, что гидролизаты органов и тканей животных представлены белковыми субъединицами и пептидами, которые характеризуются выраженной биологической активностью [5]. Важнейшим их свойством является способность ингибировать перекисное окисление липидов [6], что имеет большое значение при реализации противоопухолевой защиты, коррекции нарушений гомеостаза и для замедления процессов старения организма.

Перспективным сырьем для получения гидролизатов являются морские беспозвоночные, которые характеризуются высокой пищевой ценностью, усвояемым белком, являются источниками активных пептидов, свободных аминокислот, минеральных и биологически активных веществ [7-9]. Ферментативный гидролиз морских объектов способствует сохранению пищевых и биологически активных веществ в полученных гидролизатах. Сохранение и высокая доступность природных нутриентов в белковых гидролизатах, представляющих собой основу пищевых продуктов, способствует алиментарной коррекции обменных процессов в организме человека, повышению его сопротивляемости к негативным внешним факторам, сохранению физической активности и снижению интенсивности процессов старения. Для повышения лечебного и профилактического действия продуктов в исходный субстрат возможно введение других биологически активных веществ. 
С учетом выше изложенного, целью настоящей работы явилась разработка рецептуры и технологии белковых композитных смесей на основе ферментативных гидролизатов из дальневосточных двустворчатых и головоногих моллюсков с добавлением моноалкилглицеринов, выделенных из пищеварительной железы командорского кальмара, оценка их товароведных и биокоррегирующих свойств.

\section{Материал и методы исследований}

Объектами для получения ферментативных гидролизатов были использованы двустворчатые (гребешок приморский, спизула сахалинская) и головоногие моллюски (кальмар командорский и осьминог Дофлейна).

Для проведения ферментативного гидролиза пищевых тканей моллюсков использовали ферментный препарат «Протамекс», под действием которого в ферментолизатах исключается накопление горьких продуктов гидролиза белков $[7,9]$. Препарат «Протамекс» используется в пищевой промышленности при производстве белковых гидролизатов растительного и животного происхождения для мясных и рыбных продуктов. Активность ферментного препарата составляет 400 протеолитических единиц (далее - ПЕ) на 1 г. Он хорошо растворим в воде. Оптимальные рабочие условия находятся в достаточно широких пределах: $\mathrm{pH} 5,5-7,5$, температура активности $-35-60^{\circ} \mathrm{C}$.

Для повышения биокоррегирующих свойств композитных смесей в качестве биологически активной добавки использован препарат природных моноалкилглицеринов (1-О-алкил-глицериновых эфиров) (далее - АГЭ), которые получены из липидов печени командорского кальмара и гепатопанкреаса камчатского краба (ТУ 9281-006-02698223-10). Известно, что природные АГЭ обладают выраженной биологической активностью, проявляющейся в ингибировании атерогенных липидов, в повышении функциональной активности и выработке клеток красной и белой крови [1011]. Известно, что препараты моноалкилглицеринов положительно влияют на иммунную [12], регенеративную [13], кроветворную [14] и другие системы. Адекватный уровень потребления алкилглицеринов для взрослого человека составляет 1000,0 мг в сут. [15].

В качестве дополнительных компонентов в составе композитных смесей использовали молоко сухое, сушеные овощи, растительный жир и вкусоароматические компоненты.

Определение физико-химических показателей продуктов проводили по ГОСТ 7636 [16]. Содержание белков определяли по методу Кьельдаля с использованием автоматического прибора Kjeltec Auto Analyser 2300 (Tecator, Швеция).

где $\quad C_{2}-$ степень гидролиза образца;

Глубину гидролиза в ферментолизатах оценивали по формуле [17]:

$$
C_{2}=N_{\text {аи. }} / N_{\text {оби }} \cdot 100 \text {, }
$$

$N_{a м}$ - содержание аминного азота в образце;

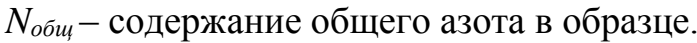

Статистическую обработку полученных результатов исследований проводили общепринятыми математическими методами с использованием компьютерных программ «Microsoft Exsel» - 2014 и «Statistica 7.0». 


\section{Результаты и их обсуждение}

Исследования двустворчатых и головоногих моллюсков показали, что по содержанию белков пищевые ткани их относятся к категории белкового сырья с низким содержанием жира (табл. 1), ферментативная обработка которого может способствовать получению вязких структур. Известно, что стойкими и вязкими эмульсиями обладают нефильтрованные гидролизаты, которые по химическому составу приближены к пищевым тканям моллюсков, а их показатели (органолептические, физические и химические) зависят от условий ферментолиза $[7,18]$. Вязкая структура ферментолизатов обусловлена частичным гидролизом белков и накоплением белковых субъединиц, обладающих структурообразующей способностью.

Таблица 1

Общий химический состав и энергетическая ценность пищевых тканей моллюсков

\begin{tabular}{|l|c|c|c|c|}
\hline \multirow{2}{*}{ Наименование } & \multicolumn{3}{|c|}{ Содержание, \% (М \pm м) } \\
\cline { 2 - 5 } & $\begin{array}{c}\text { гребешок } \\
\text { приморский }\end{array}$ & $\begin{array}{c}\text { спизула са- } \\
\text { халинская }\end{array}$ & $\begin{array}{c}\text { кальмар ко- } \\
\text { мандорский }\end{array}$ & $\begin{array}{c}\text { осьминог } \\
\text { Дофлейна }\end{array}$ \\
\hline Влага, \% & $81,1 \pm 2,3$ & $81,3 \pm 4,1$ & $79,3 \pm 2,3$ & $79,4 \pm 1,2$ \\
\hline Белок, \% & $14,0 \pm 0,9$ & $12,5 \pm 1,1$ & $15,7 \pm 1,2$ & $15,9 \pm 1,0$ \\
\hline Углеводы, \% & $2,3 \pm 0,2$ & $4,8 \pm 0,3$ & $2,2 \pm 0,3$ & $2,0 \pm 0,1$ \\
\hline Липиды, \% & $0,9 \pm 0,2$ & $0,3 \pm 0,04$ & $1,4 \pm 0,2$ & $0,9 \pm 0,1$ \\
\hline Минеральные вещества, \% & $1,7 \pm 0,2$ & $1,1 \pm 0,1$ & $1,4 \pm 0,1$ & $1,8 \pm 0,2$ \\
\hline Энергетическая ценность, ккал & $72,9 \pm 6,2$ & $71,9 \pm 5,9$ & $84,2 \pm 7,8$ & $89,6 \pm 5,0$ \\
\hline
\end{tabular}

Источник: составлено авторами

Получение гидролизатов на основе пищевых тканей моллюсков проводили следующим образом. После размораживания, сортирования и мойки пищевые ткани двустворчатых и головоногих моллюсков измельчали и готовили образцы для проведения гидролиза. К полученному фаршу из двустворчатых и головоногих моллюсков добавляли питьевую воду и раствор «Протамекса», тщательно смешивали и проводили гидролиз. Рациональные параметры гидролиза определяли с учетом, рекомендуемых в инструкции по применению ферментного препарата «Протамекс» условий (активности, температуры, $\mathrm{pH}$ ). Сметанообразная структура гидролизатов из тканей моллюсков формировалась при глубине гидролиза 29,2 $\pm 34,6 \%$, при этом вязкость составляла $11,3-11,8$ $\mathrm{m}^{2} / \mathrm{c}$. Параметры ферментативного гидролиза субстратов из моллюсков, обеспечивающие необходимую структуру, приведены в табл. 2. При повышении глубины гидролиза в ферментолизатах отмечалось расслаивание структуры, снижение вязкости и образование жидкой фракции.

Таблииа 2

Условия ферментативного гидролиза субстратов из двустворчатых и головоногих моллюсков

\begin{tabular}{|l|c|}
\hline \multicolumn{1}{|c|}{ Условия } & Значения \\
\hline Активность фермента, ПЕ/г сырья & $0,7 \pm 0,3$ \\
\hline Гидромодуль & $1: 1$ \\
\hline рН & $6,0 \pm 0,5$ \\
\hline Температура, ${ }^{\circ} \mathrm{C}$ & $37 \pm 0,3$ \\
\hline Продолжительность, ч & $2,2 \pm 0,3$ \\
\hline
\end{tabular}

Источник: составлено авторами 
Высушивание ферментативных гидролизатов проводили методом сублимации после замораживания. Процесс сублимационной сушки осуществляли в течение 12 ч при температуре не выше $60{ }^{\circ} \mathrm{C}$ до достижения влажности не более $8 \%$. Выход сублимированных продуктов составил $11,9 \pm 0,8 \%$ от веса гидролизатов, направленных на сублимацию.

После соединения с водой сухих гидролизатов их набухание до постоянного веса отмечалось через 10-15 мин, значение коэффициента набухаемости (или регидратации) составляло 8,4. Содержание воды в сухих ферментолизатах составляло не более $10,0 \%$ (табл. 3), белков - 66,1\%.

Таблица 3

Химический состав сухих ферментолизатов из двустворчатых и головоногихмол-

\begin{tabular}{|c|c|}
\hline \multicolumn{2}{|c|}{ ЛЮсков } \\
\hline Показатели & Содержание, \% \\
\hline Влага & $9,2 \pm 0,8$ \\
\hline Белок & $66,1 \pm 3,3$ \\
\hline Углеводы & $11,3 \pm 1,2$ \\
\hline Жир & $4,0 \pm 0,5$ \\
\hline Минеральные вещества & $9,4 \pm 1,6$ \\
\hline
\end{tabular}

Источник: составлено авторами

Высушенные гидролизаты из пищевых тканей двустворчатых и головоногих моллюсков использовали как основу для получения белковых композитных смесей, рецептура которых приведена в табл. 4.

Таблийа 4

Рецептура композитных смесей на основе гидролизатов из двустворчатых и головоногих моллюсков

\begin{tabular}{|l|c|c|c|c|}
\hline \multirow{2}{*}{ Компонент } & \multicolumn{4}{|c|}{ Содержание (\%) в составе смесей из } \\
\cline { 2 - 5 } & гребешка & спизуль & кальмара & осьминога \\
\hline Гидролизат & 68,5 & 69,8 & 69,2 & 67,8 \\
\hline Жир растительный & 4,0 & 4,5 & 5,1 & 4,6 \\
\hline Молоко сухое & 4,5 & 4,0 & 4,0 & 4,5 \\
\hline Пектин & 7,0 & 5,5 & 6,0 & 6,5 \\
\hline Морковь сушеная & 6,0 & 5,4 & 5,0 & 5,5 \\
\hline Лук репчатый сушеный & 4,0 & 4,5 & 4,4 & 4,5 \\
\hline Соль пищевая & 3,0 & 3,0 & 3,0 & 3,0 \\
\hline Перец душистый молотый & 0,04 & 0,05 & 0,04 & 0,07 \\
\hline Перец черный молотый & 0,03 & 0,05 & 0,06 & 0,06 \\
\hline Куркума молотая & 0,03 & - & - & 0,07 \\
\hline Корица молотая & - & 0,05 & - & - \\
\hline Рибофлавин (краситель) & 1,1 & 1,15 & 1,0 & 1,0 \\
\hline Препарат АГЭ (моноалкилглицеринов) & 1,8 & 2,0 & 2,2 & 2,4 \\
\hline
\end{tabular}

Источник: составлено авторами

Включение в состав композитных смесей таких компонентов, как жир растительный, молоко сухое, морковь сушеная и лук репчатый сушеный, обусловлено необходимостью повышения питательной ценности и созданию хороших органолептических свойств готовых продуктов. Введение пектина способствует обогащению продуктов пищевыми волокнами и повышению их вязкой структуры. Дополнительное введение специй и поваренной соли 
способствует созданию специфических вкусо-ароматических и диетических свойств питательным смесям. Так, в состав корицы входят природные полифенолы, терпены, терпеноиды и другие вещества, обладающие антирадикальным, антибактериальным, противовирусным и другим полезным действием [19]. Куркума способствует нормализации обмена веществ, улучшению кровообращения, обладает антимикробными свойствами. Рибофлавин, представляющий собой игольчатые кристаллы жёлто-оранжевого цвета, придает сухой смеси приятный светло-желтоватый цвет, а также выполняет особую физиологическую функцию в организме человека для поддержания здоровья.

Все компоненты измельчали и тщательно перемешивали. Готовые композитные смеси представляли собой порошкообразный продукт сероватожелтого цвета с равномерно распределенными вкраплениями вкусовых пищевых добавок растительного происхождения, имели приятный запах пряностей и мясной привкус.

По показателям безопасности и качеству образцы композитных сухих смесей соответствуют требованиям ГОСТ Р 53861 [1]. Химический состав и энергетическая ценность полученных композитных смесей приведена в табл. 5 . Показано, что содержание пищевых веществ в образцах смесей на основе гидролизатов из двустворчатых и головоногих моллюсков достоверно не различался.

Таблица 5

Пищевая и энергетическая ценность сухих композитных смесей

\begin{tabular}{|c|c|c|c|c|}
\hline \multirow{2}{*}{ Показатели } & \multicolumn{4}{|c|}{ Содержание (\%) в смеси на основе гидролизатов из } \\
\hline & гребешка & спизулы & кальмара & осьминога \\
\hline Влага & $12,8 \pm 0,9$ & $13,0 \pm 0,7$ & $12,7 \pm 0,6$ & $12,9 \pm 0,7$ \\
\hline Белок & $49,8 \pm 2,3$ & $48,9 \pm 2,2$ & $51,0 \pm 1,5$ & $50,4 \pm 1,8$ \\
\hline Углеводы & $20,6 \pm 1,1$ & $21,8 \pm 1,3$ & $19,2 \pm 0,9$ & $19,4 \pm 1,5$ \\
\hline Липиды & $7,9 \pm 1,0$ & $8,4 \pm 0,9$ & $8,7 \pm 0,7$ & $8,3 \pm 0,6$ \\
\hline Минеральные вещества & $8,9 \pm 1,2$ & $7,9 \pm 1,2$ & $8,4 \pm 0,9$ & $9,0 \pm 0,7$ \\
\hline Энергетическая ценность, ккал & $352,7 \pm 21,0$ & $358,4 \pm 18,3$ & $259,1 \pm 17,6$ & $260,2 \pm 17,0$ \\
\hline
\end{tabular}

Композитные сухие смеси являются белковыми, так как по содержанию белков соответствуют требованиям ГОСТ Р 53861 [1], согласно которого количество белков должно быть в таких продуктах 40,0-75,0\%.

Белковые композитные смеси фасовали по 20-30 г в пакеты из полимерных пленочных материалов, герметично запаивали на вакуумукупорочной машине при показании остаточного давления в рабочем объеме камеры 80-90 мм. рт. ст. В зависимости от массовой доли в рецептурах питательных смесей содержание АГЭ в навеске массой 20 г составляло 360,0-480,0 мг, в навеске массой 30 г - 540,0-720,0 мг. Применение композитных смесей для обогащения пищевого рациона позволяет удовлетворить суточную потребность организма человека в природных моноалкилглицеринах на 36,0-72,0\%.

Хранили белковые композитные смеси при температуре $20 \pm 2^{\circ} \mathrm{C}$ и относительной влажности воздуха не выше $75 \%$ в течение 8 мес. В процессе хранения все показатели качества продуктов сохранялись. 
Белковая композитная смесь, содержащая 540,0 мг препарата АГЭ в навеске массой 30 г, была использована в рационе питания добровольцев с нарушениями липидного обмена, возраст которых составлял 55-70 лет (группа 10 человек). Они получали в течение 30 суток по одному пакету питательной смеси, которую добавляли в первые или вторые блюда, лекарственные препараты в этот период не принимали. В лабораторных условиях ГБУЗ ККБ № 2 (г. Владивосток) до и после приема белковой композитной смеси у участников испытания были изучены показатели липидного обмена, результаты исследований которых приведены в табл. 6.

Таблица 6

Показатели липидного обмена у участников испытания до и после приема белковой композитной смеси с добавкой моноалкилглицеринов

\begin{tabular}{|c|l|c|c|c|c|}
\hline & \multicolumn{1}{|l|}{ Показатели липидного } & Единицы & Нормальный & \multicolumn{2}{|c|}{ В группе испытания } \\
\cline { 5 - 6 } & \multicolumn{1}{|c|}{ обмена } & измерения & уровень [20] & до приемa & после приемa \\
\hline 1 & Холестерин (общий) & ммоль/л & $3,2-5,6$ & $4,8-7,7$ & $4,0-5,6$ \\
\hline 2 & $\begin{array}{l}\text { ЛПВП - липопротеиды вы- } \\
\text { сокой плотности }\end{array}$ & ммоль/л & $0,78-2,2$ & $0,7-1,5$ & $1,0-1,9$ \\
\hline 3 & $\begin{array}{l}\text { ЛПНП - липопротеиды низ- } \\
\text { кой плотности }\end{array}$ & ммоль/л & $1,3-3,5$ & $4,2-4,8$ & $3,1-3,7$ \\
\hline 4 & $\begin{array}{l}\text { ЛПОНП - липоротеиды } \\
\text { очень низкой плотности }\end{array}$ & ммоль/л & $0,26-1,04$ & $0,7-1,8$ & $0,4-1,1$ \\
\hline 5 & Триглицериды & ммоль/л & $0,5-2,3$ & $1,5-3,2$ & $1,2-2,6$ \\
\hline 6 & $\begin{array}{l}\text { Коэффициент атерогенности } \\
\text { (КА) }\end{array}$ & ед. & $1,5-3,0$ & $4,1-5,8$ & $1,9-3,0$ \\
\hline
\end{tabular}

Источник: составлено авторами

Приведенные результаты исследований показали, что на фоне обогащения диеты белковой композитной смесью с природными моноалкилглицеринами у участников отмечены благоприятные тенденции изменений в липидном спектре в виде заметного снижения общего уровня холестерина и его фракций - липопротеидов низкой плотности (ЛПНП) и липопротеидов очень низкой плотности (ЛПОНП), а также содержания триглицеридов, повышенное содержание которых указывает на развитие атеросклеротических изменений сосудов [20]. Вплоть до нормального значения снизился коэффициент атерогенности (КА), увеличение которого указывает на риск возникновения сердечно-сосудистых заболеваний.

Таким образом, установлено, что введение в рацион питания белковых композитных смесей на основе ферментативных гидролизатов из пищевых тканей двустворчатых и головоногих моллюсков, обогащенных моноалкилглицеринами, способствует нормализации показателей липидного обмена и снижению риска развития его нарушений.

\section{Выводы}

Разработана технология получения белковых композитных сухих смесей, обогащенных природными 1-O-алкил-глицериновыми эфирами.

Основой для получения белковых композитных смесей является сухой ферментативный гидролизат из пищевых тканей дальневосточных и двустворчатых моллюсков. Формирование заданной структуры ферментолизатов про- 
исходит при глубине гидролиза $29,2 \pm 34,6 \%$ и вязкости $-11,3-11,8 \mathrm{~m}^{2} / \mathrm{c}$ в течение $2,2 \pm 0,3$ ч при следующих параметрах: гидромодуль - $1: 1$, активность фермента «Протамекс» $-0,7 \pm 0,3, \mathrm{pH}-6,0 \pm 0,5$, температура $-37 \pm 0,3{ }^{\circ} \mathrm{C}$.

В рецептуре белковых композитных смесей массовая доля сухого гидролизата из моллюсков составляет 67,8-69,8 \%. Дополнительно введены в состав белковых композитных смесей для повышения диетических свойств - препарат природных моноалкилглицеринов, для повышения питательной ценности и создания высоких органолептических свойств - пищевые и вкусо-ароматические компоненты.

Сухие белковые композитные смеси фасовали в пакетики из полимерных пленочных материалов по 20-30 г, в которых содержание моноалкилглицеринов составляло $360,0-720,0$ мг, что позволяет удовлетворить суточную потребность организма человека в них на $36,0-72,0 \%$. Включение в рацион питания людей с нарушением липидного обмена белковых композитных смесей, обогащенных природными моноалкилглицеринами, оказывает положительный эффект на липидный спектр в виде снижения уровня общего холестерина и его фракций, повышение которых приводит к развитию атеросклеротических изменений сосудов.

Белковые композитные смеси, обогащенные природными моноалкилглицеринами, соответствуют требованиям ТР ТС 027/2012 к специализированным продуктам для диетического лечебного и профилактического питания, рекомендованы в состав базисных и специализированных диет для снижения риска развития нарушений липидного обмена.

\section{Сиисок источников / References}

1. ГОСТ Р 53861-2010. Продукты диетические (лечебно-профилактические). Смеси белковые композитные сухие. Общие технические условия. М.: Стандартинформ. 2011. 15 c. [GOST R 53861-2010 [Produkti dieticheskie (lechebno-profulakticheskie). Smesi belkovie kompositnie suhie. Obschie tehnicheskie usloviya [GOST R 53861-2010. Products for healthful and dietetic purposes. Protein complex dry blends. General specifications]. Moscow: Standardinform, 2011. 15 p.

2. Мендельсон Г.И. Инновации в организации лечебного питания // Практическая диетология. 2011. № 1(1). С. 20-25. [Mendelson G.I. Innovazii v organizazii leschebnogo pitaniya. [Innovations in the organization of therapeutic nutrition]. Practical dietetics. 2011. N 1(1). P. 20-25.

3. Неклюдов А.Д., Иванкин А.Н., Бердутина А.В. Свойства и применение белковых гидролизатов. Обзор: научное издание // Прикладная биохимия и микробиология. 2000. Т. 36, № 5. С. 525-534. [Neklyudov A.D., Ivankin A.N., Berdutina A.V. Svoiistva i primenenie belkovih gidrolisatov. Obsor: nauchnoe izdanie. [Properties and application of protein hydrolysates. Review: Scientific Edition]. Applied biochemistry and microbiology. 2000. T. 36, N 5. P. 525-534.

4. Мухин В.А., Новиков В.Ю. Ферментативные белковые гидролизаты тканей морских гидробионтов: получение, свойства и практическое использование. Мурманск: ПИНРО. 2001. 97 с. [Muhin V.A., Novikov V.Yu. Fermentativnie belkovie gidrolisati morskih gidrobiontov: poluchenie, svoiistva i practicheskoe ispolsovanie [Enzymatic protein hydrolysates of marine hydrobiont tissues: production, properties and practical use]. Murmansk: PINRO. 2001. 97 p. 
5. Хавинсон В.Х., Кветная Т.В. Регуляторные пептиды и гомеостаз // Российский Химический журнал. 2005. T. XLIX (1). C. 112-117. [Havinson B.H., Kvetnaya T.V. Regulyatornie peptidei gomeostaz [Regulatory peptides and homeostasis] Russian Chemical Journal. 2005. T. XLIX (1). P. 112-117.

6. Морозов В.Г., Хавинсон В.Х., Малинин В.В. Пептидные тимомиметики. СПб.: Наука. 2000. 158 с. [Morozov V.G., Havinson B.H., Malinin V.V. Peptidnie timomimetiki. [Peptide timomimetics] SPb.: Science. 2000. 158 p.

7. Лаженцева Л.Ю., Лихачева Е.В. Технология белковых продуктов из дальневосточных двустворчатых моллюсков // Известия вузов. Пищевая технология. 2008. № 5-6. C. 63-65. [Lagentseva L.Yu., Lihacheva E.B. Tehnologiya belkobih produktov iz dalnevostochnih dvustvorchatih molluskov [Technology of protein products from Far Eastern bivalve mollusks]. News of universities. Food technology. 2008. N 5-6. P. 63-65.

8. Патент РФ на изобретение № 2331202. Способ получения пищевых белковых продуктов. Авторы: Шульгина Л.В., Лаженцева Л.Ю., Лихачева Е.В. Дата публикации: 20.08.2008 [Patent RF na izobretenie N 233120. Sposob poluscheniya pischevih belkobih produktov. Avtori: Shulgina L.V., Lagentseva L.Yu., Lihacheva E.B. [The method of obtaining food protein products]. Publication date: 20.08.2008.

9. Пивненко Т.Н., Ковалев Н.Н., Запорожец Т.С., Беседнова Н.Н., Кузнецова Т.А. Ферментативные гидролизаты из гидробионтов Тихого океана как основа для создания биологически активных добавок к пище и продуктов функционального питания. Владивосток: Дальрыбвтуз. 2015. 160 с. [Pivnenko T.N., Kovalev N.N., Zaporogez T.S., Besednova N.N., Kuznetsova T.A. Fermentativnie gidrolisati iz gidrobiontov Tihogo okeana kak osnova dlya sozdaniya biologicheski aktivnih dobavok k pische i produktov funkzionalnogo pitaniya [Enzymatic hydrolysates from hydrobionts of the Pacific Ocean as the basis for the creation of biologically active food additives and functional foods]. Vladivostok: Dalrybvtuz. 2015. $160 \mathrm{p}$.

10. Касьянов С.П., Латышев Н.А., Светашев В.И., Новгородцева Т.П., Караман Ю.К., Виткина Т.И. Фармакологические эффекты биологически активной добавки к пище на основе моноалкилглицеринов // Тихоокеанский медицинский журнал. 2010. № 2. C. 32-35. [Kasyanov S.P., Latishev N.A., Svetashev V.I., Novgorodzeva T.P., Karaman Yu.K., Vitkina T.I. Farmacologicheskie effekti biologicheski aktivnih dobavok k pische na osnove monoalkilglizerinov [Pharmacological effects of biologically active food supplements based on monoalkylglycerols [Pacific Medical Journal]. 2010. N 2. P. 32-35.

11. Латышев Н.А., Касьянов С.П., Блинов Ю.Г. Алкил-глицериновые эфиры морских организмов: структура, распределение и биологическая активность // Известия ТИНРО. 2012. Т. 169. С. 261-277. [Latishev N.A., Kasyanov S.P., Blinov Yu.G. Alkilglizerinovie efiri morskih organizmov: structura, raspredelenie i biologicheskaya aktivnost [Alkyl-glycerol esters of marine organisms: structure, distribution and biological activity]. Izvestia TINRO. 2012. T. 169. P. 261-277.

12. Yamamoto N.S., Claire D.A., Homma S., Ngwenya B.Z. Activation of mouse macrophages by alkylglycerols, inflammation products of cancerous tissues // Cancer Res. 1988. Vol. 48. P. 6044-6049.

13. Maulik N., Tosaki A., Engelman R.M., Cordis G.A., Das D.K. Myocardial salvage by 1-O-hexadecyl-Sn-glycerol: possible role of peroxisomal dysfunction in ischemia reperfusion injury // J.Cardiovasc.Pharmacol. 1994. Vol. 24, N 3. P. 486-492.

14. Larbi S.O. Philp R.B., Gowdey C.W. The effects of alkoxyglycerols on haematopoiesis // Arh. int. Pharmacodyn. 1968. Vol. 1. P. 78-82.

15. Единые санитарно-эпидемиологические и гигиенические требования к товарам, подлежащих санитарно эпидемиологическому надзору (контролю). Глава II. Раздел 1. Требования безопасности и пищевой ценности пищевых продуктов. М.: Роспотребнадзор. 2010. С. 398. [Edinie sanitarno-epidemiologicheskie trebovaniaya k tovaram, podlegaschih sanitarno epidemiologischeskomu nadzoru (kontrolyu). Glava II. Razdel 1. Trebovaniaya bezopasnosti i pischevoii zennosti pischevih produktov. [Uni- 
form sanitary-epidemiological and hygienic requirements for goods subject to sanitary epidemiological supervision (control). Chapter II. Section 1 . Safety requirements and nutritional value of food. Moscow: Rospotrebnadzor. 2010. P. 398.

16. ГОСТ 7636-85 Рыба, морские млекопитающие, морские беспозвоночные и продукты их переработки. Методы анализа. М.: Изд-во стандартов. 1985. 88 с. [GOST 7636-85 Riba, morskie mlekopitayuschie i produkti ih pererabotki. Metodi analiza. [GOST 7636-85. Fish, marine mammals, marine invertebrates and their products. Analysis Methods]. Moscow: Standardinform, 1985. 88 p.

17. Артюхин В.И., Шепелин А.П., Киселева Н.В. Белковые гидролизаты в производстве питательных сред: производство и применение продуктов микробиологических производств. М.: ВНИИСЭНТИ Минмедпрома СССР, 1990. Вып. 9-10. 52 с. [Artyuhin B.I., Shepelin A.P., Kiseleva N.V. Belkobie gidrolisati v proizbodstve pitatelnih sred: proizvodstvo i primenenie productov microbiologicheskih proizvodstv. [Protein hydrolysates in the production of nutrient media: production and use of microbiological products]. Moscow: VNIISENTI USSR Ministry of Industry and Medical Industry. 1990. Vol. 9-10. 52 p.

18. Богданов В.Д., Сафронова Т.М. Структурообразователи и рыбные композиции. М.: ВНИРО. 1993. 172 c. [Bogdanov B.D., Safronova T.M. Strukturoobrazovateli i ribnie kompozizii [Builders and fish compositions]. Moscow: VNIRO. 1993. $172 \mathrm{p}$.

19. Исупов В.П. Пищевые добавки и пряности. История, состав и применение. СПб: ГИОРД, 2000. 176 с. [Isupov V.P. Pischevie dobavki i pryanosti. Istoriya, sostav i primenenie. [Food additives and spices. History, composition and application]. St. Petersburg: GIORD, 2000. $176 \mathrm{p}$.

20. Климов А.Н., Никульчева Н.Г. Липиды, липопротеиды и атеросклероз. СПб: Питер Пресc. 1995. 304 c. [Klimov A.N., Nikulcheva N.G. Lipidi, lipoproteidi i ateroscleros [Lipids, lipoproteins and atherosclerosis]. St. Petersburg: Peter Press. 1995. 304 p.

21. al.gov.ru/ru/activity/statistic/rating/indeks-ekonomiki-znanij/\#tabs/Compare: Place

\section{Сведения об авторах / About authors}

Данилова Александра Львовна, аспирант Школы биомедицины, Дальневосточный федеральный университет. 690922 Россия, г. Владивосток, о-в Русский, кампус ДВФУ, корпус М.

E-mail: danilova.al@dvfu.ru

Aleksandra L. Danilova, Graduate Student of the School of Biomedicine, Far Eastern Federal University. Building M, FEFU campus, Russian Island, Vladivostok, Russia 690922.

E-mail: danilova.al@dvfu.ru

Шульгина Лидия Васильевна, доктор биологических наук, профессор, профессор Департамента пищевых наук и технологий, Школа биомедицины, Дальневосточный федеральный университет. 690922 Россия, г. Владивосток, о-в Русский, кампус ДВФУ, корпус М.

E-mail: shulgina.lv@dvfu.ru

Lidiya V. Shulgina, Doctor of Biological Sciences, Professor, Professor of the Department of Food Sciences and Technology, School of Biomedicine, Far Eastern Federal University. Building M, FEFU campus, Russian Island, Vladivostok, Russia 690922.E-mail: shulgina.lv@dvfu.ru

Приходько Юрий Вадимович, доктор технических наук, профессор, профессор Департамента пищевых наук и технологий, Школа биомедицины, Дальневосточный федеральный университет. 690922 Россия, г. Владивосток, о-в Русский, кампус ДВФУ, корпус М.

E-mail: prikhodko.yuv@dvfu.ru

Yuriy V. Prikhodko, Doctor of Technical Sciences, Professor, Professor of the Department of Food Sciences and Technology, School of Biomedicine, Far Eastern Federal University. Building M, FEFU campus, Russian Island, Vladivostok, Russia 690922. E-mail: prikhodko.yuv@dvfu.ru 
Шульгин Юрий Павлович, доктор медицинских наук, профессор, профессор кафедры инноватики, стандартизации и сертификации, Инженерная школа, Дальневосточный федеральный университет. 690922 Россия, г. Владивосток, о-в Русский, кампус ДВФУ, корпус С. E-mail: shulgin.yup@dvfu.ru

Yuriy P. Shulgin, Doctor of Medical Sciences, Professor, Professor of the Department of Innovation, Standardization and Certification, School of Engineering, Far Eastern Federal University. Building C, FEFU campus, Russian Island, Vladivostok, Russia 690922.E-mail: shulgin.yup@dvfu.ru 